Special Issue on

Public Enterprise Performance Benchmarking

Public Enterprise

Volume 22, Issue 1, pp. 1-17, 2016

https://doi.org/pehyj.2016.2201.01

\title{
Public Enterprises and the Enhancement of National Competitiveness
}

\author{
Peter K. Kresl \\ Bucknell University, Lewisburg, PA, USA
}

Received August 2015; Revised January 2016; Accepted February 2016

\begin{abstract}
The operation of public enterprises and their capability to work to enhance the competitiveness of a nation's economy in an efficient and effective manner is quite controversial. The discussion has become more intense and wide-spread as the necessity of competitiveness enhancement has increased in importance in recent years. In this paper we will examine the operation of public enterprises in two developing countries, Nigeria and India. Since these two countries are former colonies, economic activities have long been seen as being directed from out of the country and not always in the interests of the country. In recent decades, however, as independent countries each has worked to have its public enterprises operate more in line with the needs of the country. In each country there have been some successes but performance has been short of what had been desired, although assistance to technological development and education have been relatively more successful. This sort of intervention has been shown to have been more suited to the level of the regional or the urban economy.
\end{abstract}

Keywords: Public enterprise, national competitiveness, growth

Reference to this paper should be made as follows: Kresl, P. K. (2016). Public Enterprises and the Enhancement of National Competitiveness. Public Enterprise, 22(1),1-17. DOI: 10.21571/pehyj.2016.2201.01

\section{Introduction}

One of the main economic challenges confronting all levels of government (federal, state and municipal), geographic scales (national, regional and local), and participants in the private sector, is the maintenance and/or enhancement of that entity's competitiveness. Loss of competitiveness or failure to attain it condemns that entity to loss of employment, desirable skilled workers, output, the capacity to generate tax revenues to support the whole array of programs and projects, loss of place in the larger hierarchy in which it is situated, and loss of its reputation and identity. This slide to stagnation and to marginality can be caused by something completely out of the control of actors in the local economy, such as a surge in imports following a new free trade agreement, or a technological change that makes local production uncompetitive, a depletion of a resource deposit, departure of a major local employer as the result of a take-over by a firm outside the region, or an outmigration of appropriately skilled labor. 
On the other hand, in many instances, a loss of competitiveness is the direct result of decisions taken or not taken by local actors. This could allow local infrastructure investment to be ignored, failure to support adequately local educational institutions, unwise local tax and regulation/zoning policy, a laissez-faire approach to local community and business development, failure to mobilize and to integrate local actors and assets, or failure to develop the identity of the city or town and to market it beyond the local economic space. Obviously, each of the two causes of weakness in competitiveness requires its own distinct policy response on the part of local actors. This will be discussed as we progress through the argument of the text.

Work on the standard literature on competitiveness has taken as its subject either the private sector firm or the geographical/political entity such as a region, city or a metropolitan area, largely to the exclusion of public enterprises. This is because economists based in the industrialized world - that is the most familiar to them and where the data is both extensive and readily obtainable - have written much of this literature. There are certainly many studies developed by economists based in other parts of the world, and we will review the experiences of two of these developing countries: Nigeria and India.

Public enterprises are thought to be primarily features of developing countries, especially those with centrally directed economies. They are seen as principally concerned with infrastructure, public health, education, and business and community development. But many developed market-based economies have public enterprises that have responsibilities for, among others, transportation, broadcasting, and even agricultural marketing and management. Of equal interest is the fact that there are many private sector firms in specific sectors, such as transportation, education and health care, which are tightly regulated and managed by central authorities so they can be thought to function almost like public enterprises. These will be referred to here as quasi-public enterprises, defined as enterprises that are government-directed but that pursue attractive objectives to the private sector firms and that even develop these in conjunction with them. This control over private firms is done in the interest of, among others, public safety and health, and to achieve society wide minimum standards of performance or achievement. Thus, we are discussing a widely found institution.

The essential characteristic of public enterprises is that they are owned and funded by the State, they are intended to give service to the public and meet its needs; they are guided by specific socio-economic and political objectives; performance is monitored by a committee of the State; they are not designed to earn profits, they operate, as Bishnoi (2015) specified, "at the whims of the government." They usually have a monopoly in the work they do, and, in the words of Singh (2012) "there is little scope for initiative and dynamism." They are not intended to be entrepreneurial and usually have little scope for innovation. Hence, there is a general bias against public enterprises on the basis of efficiency, although that, of course, is not their raison d'être.

This would suggest that these institutions have little to do with dynamic, market responsive activities such as competitiveness. However, this is far from the truth, as it will become clear when we have examined both competitiveness as a concept and as a policy area, and how public and quasi-public enterprises can have positive or negative impacts on a city's or region's competitiveness. In the text that follows, first, we will examine competitiveness: What it is, and how it is perceived by economists and geographers. How has the notion of competitiveness evolved over time? Second, we will then relate this concept to both the private sector firms and the political or geographic area: the city and the region. How do the two applications of the concept of competitiveness differ? Third, we will review the policy discussion with regard to the enhancement and loss of competitiveness. What can local authorities do to ensure their city or region does not lose dynamism and design a strategy to achieve the desired future economy. Finally, we will get to the public enterprise and how it is related to the competitiveness of cities, regions, and private sector firms. What can the public enterprise offer that will serve the long-term interests 
of firms and the city and the region? We will suggest, in conclusion, that there is a very positive synergy between competitiveness and public enterprises in its various manifestations.

\section{Competitiveness as a Concept}

In recent decades, economists have discussed extensively both the concept of competitiveness, as it relates to geographical or political entities, and the measurement of it. Competitiveness and comparative advantage go back over two hundred years to Adam Smith and David Ricardo, and to many others, including Friedrich List in the intervening years. Almost all of them, until Alfred Marshall, focused on the national economy. Marshall (1920) introduced the concept of the industrial district, a concept that has had a great influence on the recent work on clusters as an element in competitiveness. Bruce Scott (1985) published a book based on a symposium on competitiveness at Harvard University. In his contribution he focused on two aspects: competitiveness at the level of the nation; and a rising standard of living as the primary indicator of competitiveness. This focus on the nation set the tone for many studies in the years that followed. Nevertheless, in the last decade of the $20^{\text {th }}$ century, a second track developed as cities and urban economies began to emerge as competitive actors. In 1989, Eurocities declared that "now is the time for the cities!" and the race was on (Eurocities, 1989).

Following Scott's approach, some economists countered that only the nation was an appropriate level for the study of competitiveness. Most famously, Michael Porter (1990) began a small industry with his book The Competitive Advantage of Nations. Paul Krugman (1994) found even this to be an "elusive concept", and that competitiveness was properly the concern of firms. Nations, he observed, "do not go out of business". Roberto Camagni (2002) countered that this might be the case, but that they do the equivalent experiencing long-term outmigration, stagnant investment, falling per capita income, and rising unemployment. Many economists have followed Camagni's path.

But what is competitiveness? The Oxford Compact English Dictionary (1968) defines it as "having a strong urge to win". This assumes that the purpose of the exercise is externally given, which is to win, that two or more entities strive to win the race, and that all but one of them will lose. The Random House College Dictionary (1968) states it is, among other things, "the struggle among organisms for food, space, and other requirements for existence", or "a struggle or rivalry". Here, there may be no single winner and one or more losers; each can gain food, etc., and each can participate in a rivalry as siblings and friends do, without one of them being declared the winner. Indeed, one can be competitive in the sense of being able to play the game as good as the others. Many golfers or tennis players are considered to be competitive at any given moment. Although none of them win all of the time, they are still in the game or competitive.

The notion that there is a single end to competition is one that must be contested, especially in the context in which this study is situated. There is no reason why all cities and regions cannot meet successfully the objectives of their strategic-economic plan; each will presumably have an objective that is distinctive so being successful will not preclude another city or region from achieving its specific objective(s).

Competitiveness of a firm is radically different from that of a political/ geographic area, such as a region or a city. The firm has a well-defined objective: to capture a market or beating some other firm in the competition for a contract or an order. Usually there is one winner and some losers. The ultimate objective of the firm is profit maximization and returns to shareholders. This is the same for all firms, so we can see how one firm is doing better than others. We can perceive this is reflected in the share prices on the stock exchange. Winning or losing a contract in competition with other firms will affect share prices of both the winner and the losers. Movements in share prices can be seen as a success measure or ranking in competition. 
This is not the way it works with regions and cities. While some analysts chose to evaluate cities on the basis of growth in per capita income or in the increase in GDP per capita and to rank them according to such a variable, this measure is better seen as being easier than as being relevant. This approach is similar to that of many consultants who move from one city to another like traveling vacuum cleaner salesmen, who sell the same product to all customers. In reality, not all regions or cities seek the same objective in their strategic-economic planning. They have different economic legacies, current capabilities, unique strengths and weaknesses/assets and liabilities, and aspirations. Rather than having the objective determined from above and applied in several dissimilar situations, the best city economic planning is done from the bottom up where the residents articulate their objectives for their city and its future development. There is no market or contract to be won, no movement of the share price to indicate success; there is rather a nuanced set of individualized objectives that the residents seek to achieve.

Needless to say, firms, cities and regions need the infrastructure and public goods that in most countries are provided through the activities of public enterprises. Usually, these goods are not goods that can be provided by the private sector. The investments are sometimes too great and the return on them is not high enough to be attractive. Private initiatives have given us individual toll roads, but not national road grids. Railroads are often run by the private sector today, but this is only after the initial system of tracks and rolling stock was developed by the government, and often in collaboration with a public enterprise. We will develop this linkage later in the paper but for now it is sufficient to understand that there is a direct linkage between the actions of public enterprises and competitiveness of firms, cities and regions.

The measurement of a city's or a region's competitiveness can be done using either of the two principal approaches. The first is a form of benchmarking that gathers data for a large number of variables to rank each of dozens of cities in accordance with each of the variables, and then to sum the ranking values for each city. The scores of variables are generally not carefully selected, but they are rather the variables for which data are available. The many cities can then be evaluated against the others in accordance with their "competitiveness". One is never certain if various weights should be given to each of the variables or really which of them can be taken as being important for a city's ranking or competitiveness. The second is that of selecting perhaps three variables that the literature argues are of importance to a city's economic vitality and using them to create a weighted variable that can be used as the independent variable in a multiple regression analysis. This method generates a set of perhaps 8-12 variables that can be used as determinants of competitiveness. Cities are then ranked accordingly. Here the number of variables used in the analysis is limited in comparison with the first method but the results of the exercise may be considered to be more objective.

The point of this discussion is simply to argue that competitiveness can be considered as a legitimate concept in the study of urban and regional economies, and that there are methodologies we can use to evaluate an entity's relative competitiveness. Now we must examine how competitiveness can be related to the city or urban economy.

\section{Competitiveness and the Political/Geographic Area}

The discussion has been rather general about competitiveness to this point. In this section of the paper we want to set ourselves up for the specific treatment of public enterprises and competitiveness in the final substantive section of this paper. Competitiveness of the firm, as has been noted above, is fairly straightforward with there being a general agreement as to what would indicate a competitive firm. The approach to achieving this would also be relatively

unambiguous. Things will vary a bit due to the industry in which the firm is positioned, but other than this there 
would be a general agreement with regard to the policies and strategies the firm should pursue. It is all in the execution, of course.

With cities and regions, the issue is far more complex. If we accept that the ultimate objective of competitiveness enhancement for these entities is single mindedly to achieve maximum per capital GDP or productivity, things would be relatively simple. We would want to orient the local economy toward one of the industries that are perceived to be dominant or rising. Biopharmaceutical production, ICT, or nanotechnology would be three candidates. Each of these is an industry that is projected to be one of the building blocks of the future global economy. Every geographical entity that has the possibility of succeeding in this area would be advised strongly to do orient itself to doing so. These are all high technology activities that require research facilities, a highly skilled and educated labor force, venture capital or a connection with a major multinational corporation, some investment in infrastructure, and a local environment that makes it an attractive place for the skilled workers to live, raise families, and work. It would be fairly easy to design a strategic economic plan to make a city congenial to one or the other of these industries. Invest in education and some infrastructure, establish linkages with important entities out of the area, and then sit back and let take-off. In fact, many consultants make a decent income doing just this for many cities and regions. This is the essence of top-down planning where the final objectives of the initiative are determined without significant participation of local residents or even local elites.

When we take a less standardized approach to regional and city competitiveness, the process becomes considerably more complex and nuanced. Each entity is unique in many ways and must be approached with this in mind. The residents of each place will have distinct memories of their past, understandings of what they do and do not like about the present situation, and aspirations about the future. Was the past something to cherish or to escape from? Do they think the present economy and community sustains them and gives them pleasure or does it fail them? Can they imagine a future that will meet their aspirations, including jobs for young people, the degree of social exclusion and income inequality they can tolerate, the neighborhoods, retail options and cultural and recreational activities they desire? Or do they approach the future with fear and despair? Clearly, in these regards, each region and city will be distinctive and not likely to be satisfied by a planning proposal taken "off the shelf" by someone from outside the community.

One of the first choices that must be made by a region or city that seeks to enhance its competitiveness and the vitality of the local economy is whether path dependency or path departure is to be pursued. Path dependency occurs when one location choses to build its future on the foundation and economic sectors that served it well in the past. Path departure is when the place strikes out on a new path. A classic pair of cities that capture the essence of each of these strategies and illustrates the difference between them is Chicago and Pittsburgh, in the United States. Both cities were powerfully affected by the collapse of the Industrial Heartland during the 1980s. Vital, indeed dominant, cities in the US Mid-West and Mid-Atlantic regions suffered rapid de-industrialization and deterioration as a consequence of the hike in the price of petroleum products following the action by OPEC countries in 1973 and 1979. Unemployment soared, there was out-migration of workers and their families, residential areas deteriorated, social pathologies increased, and industrial sites became derelict. Some cities such as Detroit, Youngstown and Buffalo, have been very slow to recover; however, others such as Chicago and Pittsburgh have managed to recover and to reconstitute their economy very well. The two cities took approaches to a new economy that were quite different (Kresl \& Ietri, 2015).

Chicago's past was based on three activities: heavy manufacturing, most notably steel production in the South-east quarter of the city; financial activities; transportation. In the $19^{\text {th }}$ century, the economy was oriented to meet the needs of agricultural production. Manufacturing made farm implements as well as rails; finance was primarily loans to farmers, and financing and marketing agricultural products; and transportation was to a significant degree based 
on the movement of grains and corn. For the resurgence of the Chicago economy in the late $20^{\text {th }}$ century and into the $21^{\text {st }}$, each of these activities was modernized. Manufacturing evolved into specialty steel and high tech products; finance developed new products such as currency futures and derivatives; and transportation moved from rail and canals to rail, trucking and air travel. Each activity was linked closely to the previous strength but was made competitive in the $21^{\text {st }}$ century context: this is the essence of path dependent development.

Pittsburgh was one of the principal steel production cities of the US into the post-WWII period. After the collapse of this sector, in part due to its movement to centers with modern technology and lower cost in other parts of the US and of the developing world, Pittsburgh developed economic competitiveness and strength in two new areas, areas that were in no way linked to the earlier steel economy. At the University of Pittsburgh, a very impressive collection of regional health care, medical research and medical technology was developed. At the Carnegie-Mellon University a contract for robots to do work that could no longer be done by humans in the highly-contaminated Three Mile Island nuclear facility after its melt-down in 1979 (the same year as the second of the OPEC price hikes) led to development of one of the country's primary centers of robot technology, computer science and information security. This is a classic example of the "eds and meds" (education and medicine) approach that has been successful in many cities of all sizes in recent years. Both Chicago and Pittsburgh have developed modern economies that are based on education, skilled labor, venture capital, and technology. One broke with its past, while the other built upon it and, as we shall see later, in both instances with some participation of public enterprises - in today's economy principally in education and in research.

Other cities have taken approaches to modern and competitive economies that are quite different from either Chicago or Pittsburgh. Some cities have developed as centers of recreation and leisure activity, while others are centers of culture and education. Sophisticated inter-modal transportation has sustained many urban economies, as have research and high-tech manufacturing. While some of these strategies can be pursued without much participation from outside entities, others offer classic opportunities for participation of public enterprises. There is no single approach to city competitiveness, and what a city choses to do is always a combination of local capabilities and local aspirations as expressed by the residents.

Technology and research have been the core of what Joel Kotkin refers to as "nerdistans", the cities with universities and colleges that support both research and start-ups, and highly skilled and educated workers (Kotkin, 1990). From Boston to Austin to Silicon Valley, and dozens of other cities in between, technology and the institutions that support it have been the structural core and support of some of the most dynamic urban economies in the country. This same mechanism has been applied in many other cities in Europe, Asia and elsewhere. Kotkin argues that the young skilled workers find this to be an attractive alternative to suburbs, considered to be boring, and to big cities, considered to be too frenetic and disordered. He also discusses the "revenge of the small towns", where the young skilled worker, especially those with a family, finds even the nerdistan to be unsatisfying. The advantages of small towns are basically life style and amenities, good schools, access to recreation sites such as mountains, forests, and beaches. The disadvantages of smaller cities and towns are sufficiently off-set by advantages in technological advances in telecommunications and transportation.

Charles Landry and Franco Bianchini (1995) alerted us to the phenomenon of the "creative city" and shortly thereafter Richard Florida (2001) analyzed the "creative class". Closely linked to this was the notion of innovation as a base for the competitive city, the "innovative milieu" of Roberto Camagni (1995). Peter Maskell and Gunnar Tönquist (2001) studied the Öresund region that links Denmark and Sweden as a learning region. These approaches all capture the necessity of recognizing that the contemporary economy, in almost any strategic approach requires giving attention to creativity, innovation, education, and knowledge, in what has been widely described as a 
knowledge economy. There is clearly an ample need for participation of public enterprises whatever the nature of the specific economy in a knowledge economy happens to be.

Another issue for local leaders is that of whether the competitiveness they seek is relative or absolute competitiveness. Relative competitiveness means that a city is simply doing better than another city; so that in a ranking it would be positioned higher than others. Absolute competitiveness refers to the fact that a city is actually doing better, according to some standard, than it was at an earlier time. One can be doing better relatively while all are sinking, as was the case in the 1980s in the US Industrial Heartland when all cities were negatively impacted by a general cause of decline. Chicago did better than Youngstown, but how satisfying was this? Absolute competitiveness can occur when a city is doing better when all other cities are also doing better. Does it matter that a city's 10 per cent gain in competitiveness is less than the 15 per cent gain of another city as long as the city's own objectives are being met? Hence, the usage of the term competitiveness has to be taken with the proverbial grain of salt. What usage will be most satisfying and meaningful to the residents of the community, relative or absolute?

As one can see from this discussion, the approaches taken by different cities to achieve competitiveness are quite distinctive and different and each will impose its own unique demands for resources and, of course, its own needs for assistance from public enterprises. We will examine this after we have reviewed briefly the policies that cities and regions adopt in the furtherance of their struggle for competitiveness.

\section{Policies to Enhance Competitiveness}

Cities and regions have become very active in tending to their competitiveness, their position in the global urban hierarchy, their attractiveness as a headquarters site for international organizations and corporations, their attractiveness to a desired labor force, their assets in culture and recreation that are so important for tourism, and their education and research institutions. Few cities of any size have been passive in this regard, although for some cities the task has been exceedingly difficult. To achieve these objectives, active cities and regions have aggressively promoted a number of structural and relational developments. As seen in the following discussion, this has opened the door to collaboration with public enterprises. We will develop this more extensively and explicitly in the following section.

Much of this activity has been done with reference to spatial and institutional structures. The spatial structures have received a great deal of attention during the past quarter century and we will begin our discussion with them. This all began with Marshall's (1959) treatment of industrial districts in 1890. An industrial district was comprised of a collection of firms in associated industries, or the same industry, in close proximity. This closeness would facilitate their sharing ideas, technologies, innovations in management and production, and tacit information, and they could share ideas about joint projects and generate economies of agglomeration. It was explicitly desirable for them to establish contacts with firms in other parts of the world so they could share developments taking place elsewhere; lack of this contact would lead to stagnation and ultimate collapse since they were not able to move beyond their own ideas.

Perhaps the economist who made the most of Marshall's ideas is Michael Porter (1990), who a century later, began to develop and to promote the idea of clusters as key elements in the promotion of competitiveness. Clusters are firms that are situated in close proximity; they consist of a spatial concentration of firms in the same industry and one would expect that they would have all of the interaction that Marshall argued would take place in an industrial district. Many clusters do in fact operate in this way and cluster development has been a primary element in the planning for industrial development of a city or a region. The Competitiveness Institute, founded on Porter's 
writings and concepts, states boldly and unequivocally that "competitiveness is clusters". However, in many industries dominated by large firms with subsidiaries where proprietary knowledge is important, there may be little or no interaction among the subsidiaries of various firms in one spatial "cluster". In biopharmaceutical this is the case and the flow of information may be principally downward from the parent to the subsidiary (Simmie, 2005). In other clusters, links with the world beyond the cluster are lacking and the cluster stagnates since it misses out on the technological innovations that are taking place elsewhere (Malmberg, 2002). Finally, in some clusters knowledge transfer comes from outside the cluster and the tacit transfer of knowledge among cluster participants - so vital to Marshall's industrial districts and to true clusters - is missing. In short, clusters are not always true to the essential characteristics of Marshall's conceptualization of industrial districts. When properly functioning they are very important to development of a regional urban economy, but they are not a panacea.

For smaller cities, where mere size precludes any significant development of clusters, an attractive option is participation in one or more networks. A network is essentially a cluster that lacks proximity and may be extended to whatever scale is most useful to its participants. They can be thought of as clubs with limited membership, with obligations for activity and members can be expelled from the network if the participation is not of benefit to other members. They can gain access to knowledge and technology, build coalitions, participate in joint projects, and share the best practices. This structure is also of importance to cities that are on the periphery or are isolated from other city contacts. Capetown, Lisbon, and Brisbane are three good examples. Advances in both telecommunications and transportation make networks feasible and not excessively costly.

Another structure that has been given a lot of attention is that of the "triple helix". This structure is made up of three entities: universities, the private sector, and government. The objective of establishing this structure is to promote technological advance and transfer, and to generate the start-up of small firms that benefit most from such a structure (Etzkowitz, 2001). Etzkowitz writes of one model found in the Soviet Union and more recently in Latin America in which the government was central and supreme and in which universities and companies were subordinate to state-owned industries that were dominant. A second model was found in the US in which the state, universities and industry were distinct and separate entities. This model had the advantage over the Soviet-Latin American one in that it was bottom-up in its orientation and therefore oriented to the market and to useful products, rather than top-down and oriented to internal government objectives. The "triple helix" model by contrast has the three set as overlapping circles in which each is responsive to, supportive of and supported by the other two entities.

While it is clear that clusters and networks may have no need for government or for public enterprises, other than for funding of infrastructure and some educational institutions, the "triple helix" has government, and by extension public enterprises, at its core. Government is now seen as a central player in the development and application of technologies - communication, production and transportation, in collaboration with universities and the private sector. We will discuss this in greater detail in the next and final section of this paper.

The final aspect of policy for regions and cities we will examine is that of provision of amenities that will attract skilled workers and desired firms to the location. Highly skilled and educated workers are very mobile. They do not have to work in any specific city if it is not congenial to them and if they do not provide the life style and amenities they insist on having for their families. Hence, it is the responsibility of any region or city that wants this sort of labor force to ensure that there is adequate provision of schools, health care, recreation, cultural institutions, parks, housing in pleasant neighborhoods, and so forth. In some of these aspects the advantage goes to larger cities while in others smaller cities are more desirable. Many tech workers have no need of a major hub airport since they find it more convenient to share ideas, plans, etc., through modern telecommunication. This, of course, mandates that competitive cities ensure that high-speed connectivity, etc., are available at reasonable cost. 
Similar concerns are present with regard to making a region or city attractive to firms that local authorities would like to have as key entities in the local economy. Here facilities such as a hub airport, major highway and rail connections for logistics, zoning and local regulations, local taxes, access to capital and an array of professionals in certain areas, and so forth can be instituted by local authorities. Depending on the national culture and political structures, some of this may be done by quasi-public enterprises. Most cities have a local chamber of commerce, a better business bureau, and other organizations that, with assistance from local government, integrate a firm in the local business community. Obviously this is of greater interest to smaller firms and to start-ups.

\section{The Role of Public Enterprises in Competitiveness}

We have taken a rather long road to get to the key issue at hand - the role of public enterprises in competitiveness. Partly, this was done to give a sufficiently clear notion of what competitiveness is and how it relates to the policies of regions and cities; partly, it was done to gain an understanding of what spaces there are for public enterprises to contribute to the effectiveness of local efforts to maintain and enhance competitiveness. Due to the experience and knowledge of the author the discussion that follows will be concentrated on the role of public and quasi-public enterprises in the US. Following this will be a much shorter examination of the role of public enterprises in two key countries in the developing world - India and Nigeria.

\section{In the United States}

Public enterprises have had a long history in the US, but owing to the predominant role played in the US economy by the private sector; these institutions have been overshadowed when it comes to playing a central role in the competitiveness of the national economy. But throughout the past 150 years public enterprises have at times been crucial to the development of the economy. The event that made this possible was the Civil War between 1861 and 1865. During these years the Senate and House of Representatives were devoid of any legislators from southern, conservative, and anti-national government states. In their absence Washington was able to pass legislation that established the government role in the creation of the trans-continental railway (the Pacific Railroad Acts), precourser to the Inter-State Highway Act almost a century later, the Land Grant College Act (the Morrill Act) that established a system of public, state universities, and the Homestead Act that opened the west to settlement. These acts created initiatives and public enterprises that promoted the development and competitiveness of the national economy.

In more recent years we have other institutions such as the Tennessee Valley Authority that managed flood control, irrigation and rural electrification throughout much of the south. This was duplicated in other parts of the country, most notably with Hoover Dam on the Colorado River that generated electricity and managed water use in the south-west, and the hydro-electric dams on the Columbia and other rivers in the north-west. The latter were to provide the power that would convert bauxite into aluminum and stimulate the growth of aircraft production during the Second World War and in the ensuing years. In what follows we will examine more closely the role of public and quasi-public enterprises in four areas of the development of the competitiveness of US cities and regions.

Provision of an adequate transportation infrastructure is a primary responsibility of both federal and state government agencies. State highway commissions have done much to develop the high-speed road travel system in the country for by passenger and truck traffic. Quasi-public enterprises such as the Port Authority of New York and New Jersey are responsible for inter-state tunnels and bridges. Others have been responsible for working with the private sector to create the current array of airports, from regional airports to international hub airports in every significant city in the country. Other similar entities have created the efficient rail connections between the airport 
and the city center in virtually all major cities. Previously this was done by taxi companies but when the corporate facilities dispersed throughout the metropolitan regional area, the city and the airport commission cooperated to construct the rail linkages to the city centers.

In Europe, the most dramatic transportation initiative in recent memory has been the high-speed rail system, starting with the TGV system in France. A few lines at the outset have been expanded to a network that covers much of the national space. Being France, the system has Paris as its hub, the center-south of the country is not well served, and east west links other than those based on Paris are almost absent. What is striking is the impact being on a TGV line has had on the fortunes of individual cities (Thompson, 1994). Cities such as Tours, Le Mans and Rouen that have good service can function as bed-room communities for Paris or as work places for Parisians. Other cities such as Orleans, Limoges and Clermant-Ferrand, as well as most smaller cities, are out of the system and do not have these options and many of them have become marginalized.

The French rail system is designed and managed by the state rail company, SNCF, and the system is responsive to the needs of national economic development rather than the needs of the regions, although regions with political clout do, of course, have an advantage. This suggests both the advantages and the disadvantages of having a public enterprise actively engaged in competitiveness enhancement policies in which a strong economic rationality is not always imposed on the decision-making process.

While the French model has been adopted by most of the rest of the Continental countries, the United Kingdom stands out as a contrast, and not to its benefit. When Prime Minister Thatcher destroyed the "greater x city councils" there was no municipal power that could be joined with that of other cities to pressure for infrastructure projects. The most glaring of these was the lack of a high-speed rail link from Scotland, via Manchester-Liverpool, and Birmingham to London, with connection with the continental network. Rail has always been provided by private companies in the UK, and governments have been reluctant to try to impose a national rail grid on the country. It is only now that there is some progress being made toward a west-coat high-speed rail link, and that in about ten years at best. There is no UK public or quasi-public enterprise in rail transportation as there is on the Continent; a very interesting contrast.

Another example of government involvement in an element that is important for regional or urban competitiveness is government support of municipal/public art and architecture. Major buildings of outstanding architecture can have the effect of giving a city an identity or brand that gives it recognition throughout the world. Many cities have artifacts and structures that have been inherited from the past but of more interest here are the structures that have been created or at least funded by local government. Perhaps the most famous of these structures is the Eiffel Tower in Paris, which was built for the 1889 World's Fair under a contract from the government of France. It was to symbolize the abilities and art of modern engineering and the age of science and industry. It has served as an icon of the city ever since and has given an identity to people throughout the world. Needless to say its draw for tourism and business has contributed much to the success and competitiveness of Paris for a century and a quarter.

One of the most successful initiatives to create a building that would identify the city internationally is the Guggenheim Museum in Bilbao, Spain, in the Basque region. Funded by the Basque government, and designed by architect Frank Gehry, the museum was inaugurated in 1997. Gehry's design of metal curved sheets evoking the sails of the ships that historically created Bilbao's wealth, is so striking that it has become recognized as one of the premier buildings in the world and has revitalized the Bilbao economy through the impacts of tourism and business development. 
In North America and Europe most of the notable buildings of recent years have been funded by the private sector: developers, or financial or industrial entities. However, one notable exception is the World Trade Center, which opened in 1973 and, after their destruction in 2011, One World Trade Center, or "Freedom Tower", in Manhattan. The agency behind the concept and the funding of these buildings that gave such an identity to New York City was the Port Authority of New York and New Jersey, an agency of the two states. A private developer was involved in the second building, One Freedom Tower. These buildings served the function of confirming the place of primacy of New York City in the world of finance.

Other significant buildings created by public enterprises are all in Asia. The objective of many of these initiatives was that of creating the tallest building in the world or some other characteristic that would establish the host city as a place of importance in the global urban hierarchy. The Petronas Towers in Kuala Lumpur, Malaysia, surpassed the Willis (Sears) Tower of Chicago as the tallest building in the world in 1998. The objective of the government was to leapfrog ahead of other cities in Asia for the key place in their regional economy. Shanghai responded quickly with three buildings, the Jin Mao Tower, Shanghai World Financial Center and Shanghai Tower. While private companies were involved in the design and in the construction, the concept of the three super-tall buildings was that of the Shanghai government, the participation of which was the sine qua non of the initiative (Dupré, 2013).

The most notable example of this use of public enterprises to use architecture to put a city on the map, so to speak, is, of course, Dubai. The intent was clearly that of making Dubai the principal financial and tourism center of the Middle East. The first step was creation, in 2009, of the Palm Jumeirah, a residential-hotel development set on a structure of man-made islands out into the sea. Equally dramatic was the sail shaped Burj Al Arab that was intended to do for Dubai what the Opera House did for Sydney and functions as a hotel and retail center. It was opened in 1999. The final piece in Dubai's architectural call for attention was what in now the world's tallest building, the Burj Khalifa, completed in 2010. It is a financial and recreational center that is just over 2,700 feet in height. Not to be outdone, however, Saudi Arabia is planning its Kingdom Tower for completion in 2018. Its height will be 3,281 feet and, therefore, the world's tallest building, for now.

These architectural triumphs in Asia and the Middle East are the result of cooperation between the government, public enterprises and private sector firms. They demonstrate the dramatic results that can be achieved through this sort of initiative. The structures do not always make sense from the standpoint of economics narrowly perceived, but when linked with a desire to dramatically increase the international recognition and status of the place in which they are constructed, and hopefully to enhance the city's global competitiveness, the rationality is put in a different light.

The role of government in the support of research and new products in the US is shown clearly by the activities of the Department of Defense's Defense Advanced Research Projects Agency (DARPA), and the National Institutes of Health, or NIH. Founded in 1958 in response to the Sputnik initiative of the USSR, with a current annual budget of \$2.8 billion DARPA functions similarly to a public enterprise but rather than doing research itself it issues contracts to universities, firms and research labs directly or through specific competitions. This is clearly the US approach to funding research as opposed to the state-centric model in which firms and universities are subsumed within government itself. For example, in 1982 it issued a contract to a professor at Carnegie-Mellon University, William Whittaker, to build a robot to work within the Three Mile Island nuclear facility after its 1979 meltdown. This established a "field robotics" program and a similar one in "space robotics". This has led to a series of devices for work with the space program and nuclear installations around the world, and other initiatives as well. This has led to Carnegie-Mellon being one of the premier universities in this area of research; it has also contributed importantly to enhancing the competitiveness of Pittsburgh in its post-steel rebirth as an important city. As noted above the other element in the rebirth of Pittsburgh has been regional health care, medical technology and medical research, based at the University of Pittsburgh, a state-related research university. This sector too is heavily dependent upon grants and 
contracts from agencies such as the NIH and Commonwealth of Pennsylvania research agencies. NIH is the largest funder of biomedical research in the world. It's funding, about $\$ 30$ billion, supports individual research projects as well as the operations of centers and programs. NIH grants to the University of Pittsburgh have averaged about $\$ 450$ million in recent years. One of the most important consequences of this funding is the growth of start-up firms in the area of medical technology and health care.

Hence, it is clear that in both of the sectors that are sustaining the competitiveness of Pittsburgh's economy, government agencies, such as DARPA and the NIH, functioning as the equivalents of public enterprises have played crucial roles. DARPA holds regular conferences with researchers in universities, firms and laboratories to discuss what the most promising and important areas of research will be in the coming years. It then responds to this input in designing its competitions and contracts. Both entities are prime examples of the twist the US has given to the notion of public enterprises. State funding, state direction but with input from the research communities, grants issued to universities, firms and research laboratories that are usually completely separate from government. This model of quasi-public enterprises is relevant also to several other government departments, most notably Transportation and Agriculture. It maintains the US separation of the elements in the "triple helix" but imposes a close cooperation among them.

Education and knowledge generation are two other tightly linked aspects that public enterprises and quasi-public enterprises can work on that lead directly to a region's or to a city's competitiveness. We have just seen how agencies in the US, among others DARPA and the NIH, have supported university research programs and the furtherance of knowledge in general. But other agencies of the state and federal government give vital support to all universities through student grants and loan programs, such as Pell Grants and Title VI programs. Furthermore, most of the large research universities in the US are public, state-funded universities, such as the University of California campuses, the Big Ten (except for Northwestern University) universities, and major universities in virtually all other states. Undergraduate and graduate study programs are supported as they are the full array of research programs, centers, institutes, and so forth. They may be considered to be quasi-public enterprises. Highly regarded universities are seen by state and local leaders as essential elements in the development of the economy, in creation of a skilled labor force, in generation of tech-based start-up firms, and in attraction of firms, large and small, from outside the region to situate production and research facilities in the state. Hence, they are seen to be central to competitiveness enhancement of the city and state in which they are situated.

\section{In Nigeria and in India}

This will in no way be a comprehensive treatment of the role of public enterprises in the developing world or even in these two countries but, rather, it will afford us a glimpse into the extent and nature of their role in the development of the economies and the competitiveness of these two classic cases. The reader is encouraged to explore this issue in greater detail in other and more authoritative sources.

In general, we can say that public enterprises in developing countries serve an extensive set of purposes. Their mandate is based on the experience these countries had with the earlier colonial system that was managed by European powers. These colonial powers established railroad, mining, harbor, and other government-chartered enterprises to accomplish the management of the economic management of the colony. Following the Second World War government involvement in the European economies was increased for introduction of the welfare state, to provide employment and to do economic activities that the private sector was not yet capable of doing, if only for shortage of capital for investment. In developing countries public enterprises used government funds for investment in facilities for transportation, mining and mineral extraction, manufacturing, education, and other services, 
including those related to the welfare state. The enterprises were mandated to implement government policy objectives, provide basic goods and services to the public regardless of income, protect the consumer, provide infrastructure and public goods, and pursue national security.

In Nigeria after liberation from colonial status the government was reluctant to allow British or other foreign companies own and manage major infrastructure entities such as the national railway network that was needed, among other things, to link producers and harbors so goods could be exported. By the 1980s there were 275 public enterprises at the national level and additional 600 at the state level (Tsunabavyon \& Orokpo, 2014). Prominent among these were Nigerian Telecommunication, National Electric Power Authority, Nigerian Railway Corporation, Nigerian Produce Board and Development Board, entities that were patterned on the British model. Public enterprises accounted for 22 per cent of total employment, and one-third of public sector employment and 35 per cent of GDP. They were involved in production ranging from agriculture and food processing to assembly of automobiles. They were charged with providing "goods and services for the cultural, social and economic upliftment (sic) of the citizen" (Ogohi, 2014). The oil boom of the 1970s gave the government the opportunity to become dominant in a new major economic activity and also access to the revenues it needed for support of the public enterprises, among other things.

The objectives of the public enterprises in Nigeria were specified in the national constitution. They were "to secure the maximum welfare freedom and happiness of every citizen on the basis of social justice and equality of status and opportunity." Furthermore, they should ensure: a planned and balanced economic development; that the material resources of the country should be distributed so as to serve the common good; that wealth is not concentrated; and "that suitable and adequate food, reasonable national minimum wage, old age care and pensions, and unemployment and sick benefits are provided for all” (Onyemenam, 2013).

Clearly, the objectives or tasks of public enterprises in Nigeria were those that could not be given to private sector actors. Either they lacked the capital to make the necessary investments, or their profit-maximizing goal was not in conformity with national objectives for economic actors. Public enterprises were developed in part because of the inability of private sector firms to meet the desired objectives of government or because of an ideological preference for state actors that were not governed by capitalist system goals. In any event, public enterprises were adopted with enthusiasm in Nigeria as was the case in many other African nations. Onyemenam tells us that public enterprises and the role of the state were pressed more aggressively in countries such as Algeria, Guinea, Malagasy and Tanzania but less so in others, Cameroon, Kenya, Gabon and Ivory Coast (Onyemenam, 2013).

However, in almost all of these countries public enterprises came under attack in the 1980s and 1990s. In Nigeria, the Structural Adjustment Program of 1986 sought to reform these institutions so as to improve their efficiency and to develop more effectively the growth potentials of the private sector (Tsunabavyon \& Orokpo, 2014). The issue here, as in most other African countries, is the failure of public enterprises to achieve their objectives. A general critique is that they were inefficient, corrupt, mismanaged, overly bureaucratic, monopolistic, overstaffed, sink-holes for government revenues, subservient to political masters, and operating in opposition to national economic development. In many African countries there was a groundswell of rejection of public enterprises and an enthusiastic embrace of privatization and economic rationality. This process is not yet completed but public enterprises will now have to seek out a role they can play in national economic development.

In all of this there is virtually no discussion of what public enterprises can do to enhance national or regional or urban competitiveness. What they provide, in terms of infrastructure, education, and so forth, do however contribute powerfully to the ability of the nation to achieve objectives in international markets. This is not to say that they are always successful, but what they do is essential for the competitiveness of a developing economy. On the other 
hand, the corruption and mismanagement of these entities has caused much negative impact on Nigeria's ability to competitive in international markets.

Our other case, India, follows much the same pattern but with a higher level to performance and competence. India's policy with regard to public enterprises and to the mix of public and private entities was clearly detailed in a series of Industrial Policy Statements, beginning in 1948, Five Year Plans, beginning in 1951-56, and the Industrial Policy Resolution of 1956. There were four broad categories of industries with three degrees of government and public enterprise involvement and one that was open to the private sector. This is far too detailed for exposition here but basic industries from iron and steel to military goods to essential infrastructure and public utilities were reserved for public enterprises of one sort or another, as were those requiring large scale investment. By 1991 there was growing frustration over the performance of public enterprises in industry. They were seen to be chronically sick and not able to be reformed. Many were characterized by over staffing, inadequate of monitoring of performance, underutilization of capacity, poor labor management relations, lack of coordination with other enterprises, and so forth (Mishra, 2014). As a consequence, there began a process of government disinvesting in these public enterprises. As an alternative the government introduced a series of Special Economic Zones, a program of subsidies, and efforts to strengthen the private sector and entrepreneurship. Unfortunately, these initiatives have been less successful than was anticipated. One problem is the need for land by the zones and this can only be obtained from peasant farmers who have not been pleased by the experience. Another is that only a few of the many zones have actually been successful in generating substantial exports. The experience has been that both the public enterprises and the special export zones have, in anything, detracted from the competitiveness of India's regions and the national economy, with the exception of a few well run public enterprises and the provision of basic infrastructure and public goods. Most of the considerable growth and international success of India's information technology and high-technology sectors has occurred in the private part of the economy.

\section{Final Words}

The objective of this paper was the exploration of the relationship between public enterprises and competitiveness. Specifically, what could public enterprises do to enhance competitiveness of firms, regions, and cities? The focus was on the situation in industrialized countries with analysis and experiences coming predominantly from the US. We briefly examined the situation in the established private sector firms and concluded that they were not a promising area of inquiry. It is true that quasi-public enterprises can have a very positive impact on start-ups of new firms in technology-based sectors through their support of education and research and the contracts they issue. Nevertheless, beyond this, there has not been done much in the US. The situation in Europe would probably be quite different given the different and closer structural relationships between the public and private sectors; but this would be the topic for another paper.

The situation has been shown to be quite different when it comes to public enterprises and the competitiveness of regions and cities. In our review of competitiveness and of the policies that regions and cities adopt with the objective of its enhancement we highlighted several specific ways in which public and quasi-public enterprises could assist regions and cities. There is not much that can be done with regard to two of the most important structures for cities: clusters and networks; perhaps some infrastructure, but not much else. However, the third structure, the "triple helix", is explicitly based on interaction between universities, private sector firms and government/public enterprises. This has been a very rich and productive interaction throughout the industrialized world. One of its features is that since the government/public enterprise does not dominate decisions and actual activities, what is done tends to be bottom-up and directly linked to economically rational, market-oriented, new product, and new firm activities. The alternative model was based on everything being subordinated to the 
government and organized in accordance with the government political objectives and plans. Clearly, this approach had no necessary connection with competitiveness enhancement.

We also highlighted the positive consequences that public enterprises have through provision of infrastructure projects, such as high-speed rail, expressways for cars and trucks, and airports. These initiatives are typically a combination of public enterprises, and private sector firms. The infrastructure that is provided is a powerful contributor to regional and urban competitiveness. The same can be said of the impact on international reputation and recognition or branding of regions and cities of public art and architecture projects, such as the Guggenheim Museum in Bilbao, the Petronas Towers in Kuala Lumpar, and the structures that put Dubai on the map as a principal financial and tourist center in the Middle East. All of these were accomplished with the cooperation of private sector firms, government, and public enterprises.

The final area we explored was the impact of public enterprises on research, knowledge creation, and education. We used Pittsburgh as an example of how this worked. DARPA has had its impact on development of the internet and centers of robotics and computer science, on behavioral science, and on many areas of technology. The NIH has had a similar impact on biomedical research and production. One of the consequences of the competitions and contracts issued is on the development of new, technology-related small business and start-ups. This has had a powerful impact on many local economies throughout the country and has greatly enhanced their competiveness.

In some countries purely public enterprises are the principal feature, but in others in the industrial world in which government direct participation is not predominant, quasi-public enterprises are more common. Whichever form this takes it is clear that the participation of these enterprises in projects with private firms, universities and research laboratories is a powerful contributory factor in the ability of regions and cities to maintain their competitiveness or to become more competitive.

The experience of Nigeria and India is one of greater reliance on public enterprises as key engines of growth and competitiveness; however, beyond some initial positive impacts and the effects of provision of infrastructure and public goods the experience has been disappointing. A few enterprises have been well run and have contributed to the competitiveness of the national and regional economies but seemingly inevitably waste and inefficiency work against this enhancement of competitiveness.

\section{Conclusion}

In conclusion, we find that public enterprises have been very useful in the development of the infrastructure and support of education and research that are required by successful private sector firms, the entities that contribute most directly to competitiveness. In the contemporary economy characterized by the rapid technological development of production, communication and transportation, the rise of new competitors somewhere in the world, and the importance of knowledge rather than manual labor: OMIT COMMA, government dominated enterprises lack the flexibility and adaptability to do much more to enhance competitiveness, as they are less central than they were at earlier stages of development. 


\section{References}

Bishnoi, B. (2015). Meaning, definition and characteristics of public enterprises. Retrieved from

http://www.publishyourarticles.net/knowledge-hub/business-studies/meaning-definition-and-characteristics-ofpublic-enterprises/763/

Camagni, R. (2002). On the concept of territorial competitiveness: Sound or misleading? Urban Studies, 39(13), 2395-2411. dx.doi.org/10.1080/0042098022000027022

Camagni, R. (1995). The concept of the innovative milieu and its relevance for public policies in European lagging regions. Papers in Regional Science, 74(4), 317-340. dx.doi.org/10.1111/j.1435-5597.1995.tb00644.x

Dupré, J. (2013). Skyscrapers: A history of the world's most extraordinary buildings. New York, NY: Black Dog and Leventhal Publishers.

Etzkowitz, H. (2001). The triple helix of University-Industry-Government: Implications for policy and evaluation (Working Paper No. 2001-11). Stockholm, Sweden: Institutet för studier av utbildning och forskning.

Eurocities. (1989, April). Documents and subjects of Eurocities conference. Presented at the Committee of the Eurocities Conference, Barcelona, Spain.

Florida, R. (2001). The rise of the creative class. New York, NY: Basic Books.

Kotkin, J. (1990). The new geography. New York, NY: Random House.

Kresl, P., \& Ietri, D. (2015). Urban competitiveness: Theory and practice. London, UK: Routledge.

Krugman, P. (1994). Competitiveness: A dangerous obsession. Foreign Affairs, 73(2), 28-34. dx.doi.org/10.2307/20045917

Landry, C., \& Bianchini, F. (1995). The creative city. London, UK: Demos.

Malmberg, A. (2002). Klyster dynamic och regional näringslivutvekling, Österdund, Sweden: Institute för tillväxtpolitiska studier.

Marshall, A. (1959). Principles of economics ( $8^{\text {th }}$ edition). London, UK: Macmillan and Company.

Maskell, P., \& Gunnar, T. (2001). Building a cross-border learning region. Copenhagen, Denmark: Copenhagen Business School Press.

Mishra, R.-K. (April, 2014). Role of state-owned enterprises in India's economic development. Presented at Workshop on State-Owned Enterprises in the Development Process Conference, Organization for Economic Cooperation and Development, Paris, France.

Ogohi, D. (2014). Analysis of the performance of public enterprises in Nigeria. European Journal of Business and Management, 6(25), 24-32.

Onyemenam, C. (2013). Problems facing public enterprises in Nigeria. Retrieved from http://articlesng.com/problems-facing-public-enterprises-in-nigeria/

Oxford Compact English Dictionary. (1996). Oxford, UK: Oxford University Press.

Porter, M. (1990). The competitive advantage of nations. New York, NY: The Free Press.

The Random House College Dictionary. (1968). New York, NY: Random House.

Scott, B. (1985). U.S. Competitiveness: Concepts, Performance, and Implications. In B. R. Scott \& G. C. Lodge (Eds.), U.S. competitiveness in the world economy (pp. 13-70). Cambridge, UK: Harvard Business School Press.

Simmie, J. (2005). Innovation clusters and competitive cities in the UK and Europe (Report No. L130251051). Swindon, UK: Economic and Social Research Council.

Singh, S. (2012). What are the important characteristics of public enterprises? Retrieved from http://www.preservearticles.com/2012022823827/what-are-the-important-characteristics-of-publicenterprises.html.

The Competitiveness Institute. (n.d.). Retrieved from www.tci-network.org.

Thompson, I. (1994). The French TGV system - progress and projects. Geography, 79(343), 164-168. 
P. K. Kresl (2016)

Public Enterprise

Volume 22, Issue 1, pp. 1-17, 2016

https://doi.org/pehyj.2016.2201.01
International Center for

Promotion of Enterprises

Tsunabavyon, A.-P., \& Orokpo, O.-F.-E. (2014). Performance of public enterprises in Nigeria and the privatization option. International Journal of Public Administration and Management Research, 2(2), 148-155.

\section{Author Note}

Correspondence concerning this article should be addressed to Peter K. Kresl, Charles P. Vaughan Professor of Economics Emeritus, Bucknell University, Lewisburg, PA 17837, USA. Email: kresl@bucknell.edu

\section{Biographical Note}

Peter Karl Kresl has been researching and publishing aspects of urban competitiveness for over 15 years. He is cofounder and president of the Global Urban Competitiveness Project, a group of 17 scholars working in this area. His recent books have been on subjects such as: the place of smaller cities in the global economy, the impact of an aging population on urban economies, and planning cities for the future, and is currently writing a book on how cities use architecture. His Ph.D. is from the University of Texas and he is professor of economics emeritus at Bucknell University, USA. 